\title{
Inhibition of DNA Virus: Herpes-1 (HSV-1) in cellular culture replication, through an antioxidant treatment extracted from rosemary spice
}

\author{
Dalva Assunção Portari Mancini ${ }^{*}$, Rosângela Pavan Torres², José Ricardo Pinto', \\ Jorge Mancini-Filho
}

\author{
${ }^{1}$ Virology Laboratory, Division of Scientific Development, Butantan Institute, ${ }^{2}$ Lipids Laboratory, Food Science \& Nutrition \\ Department, Faculty of Pharmaceutical Science, University of São Paulo
}

\begin{abstract}
This work aimed to evaluate antiviral properties in antioxidants from spices. Phenolic compounds extracted from rosemary (Rosmarinus officinallis, L) by hot water, had their antioxidant activity determined by spectrophotometry using $\beta$ carotene/linoleic acid system. The rosemary extract was evaluated by antiviral assay of Herpes Virus type-1 (HSV-1) replication in VERO cells, in the presence or absence of the spice. $10,000 \mathrm{TCID}_{50} / \mathrm{mL}$ of the HSV-1 was kept for $3 \mathrm{~h}$ at $4^{\circ} \mathrm{C}$, with $300 \mathrm{ppm}$ of rosemary extract, and 100 ppm of butyl hydroxyl toluene (BHT). Then, these viruses were inoculated in VERO cells incubated at $37^{\circ} \mathrm{C}$ in $\mathrm{CO}_{2}-5 \%$, for seven days. Daily, they were examined and the end point was based on $100 \%$ of $\mathrm{CPE}$ in virus control (without antioxidants). The HSV-1 replication inhibition percentage (IP) measured the antiviral action from antioxidants, showing viral reductions of the $82.0,82.5 \%$, in the presence of rosemary and rosemary + BHT, respectively. As an extension, cell test corresponded to the similar viral decrease (IP $=85.0$ and $86.3 \%)$ in both aforementioned situations. Results lead to conclude that phenolic compounds from rosemary revealed an antiviral action on herpesvirus-1.
\end{abstract}

Uniterms: Natural antioxidants. Virus replication. Phenolic compounds. Herpesvirus. Rosemary.

Neste estudo foi avaliada a ação antiviral de antioxidantes de especiaria. Extrato aquoso de alecrim (Rosmarinus officinalis, L), que apresentou atividade antioxidante através de espectrofotometria usando o sistema $\beta$ caroteno/ácido linoléico, foi avaliado em ensaios com vírus herpes-1 na replicação em células VERO. Nestes ensaios foram utilizados $10.000 \mathrm{TCID}_{50 \% / \mathrm{mL}}$ do vírus HSV-1, mantidos em contato com $300 \mathrm{ppm}$ do extrato de alecrim e com $100 \mathrm{ppm}$ de butil hidroxi tolueno (BHT), durante $3 \mathrm{~h} \mathrm{a} 4^{\circ} \mathrm{C}$. Esses vírus, em seguida, foram inoculados em células VERO incubadas a $37^{\circ} \mathrm{C} / 5 \%$ de $\mathrm{CO}_{2}$ por sete dias. Pelo efeito citopático (ECP) e o "end point" de ECP do controle de vírus (sem antioxidante), foi possível observar que houve reduções na replicação viral de 82 e $82,5 \%$ na presença do alecrim e do alecrim + BHT, respectivamente. Nessa situação,avaliou-se ainda a redução da adsorção viral às células, que apresentou índices similares de 85,0 e $86,3 \%$ de redução na capacidade da adsorção. Estas reduções no desempenho do HSV foram medidas pela fórmula de porcentagem de inibição da replicação viral (PI). Os resultados levam a concluir que os compostos fenólicos do alecrim apresentam ação antiviral sobre o HSV-1.

Unitermos: Antioxidantes naturais. Replicação viral. Compostos fenólicos. Vírus herpes. Alecrim.

\section{INTRODUCTION}

Since the early studies of antiherpetic drugs, their

*Correspondence: D. A. P. Mancini. Virology Laboratory, Division of Scientific Development, Butantan Institute, Av. Vital Brasil, 1500 - 05503-900 - São Paulo - SP, Brazil. E-mail: dapmancini@butantan.gov.br role has been observed on the decrease of viral multiplication, in vitro, as well as in vivo. The generally used synthetic antiviral acyclovir [9(4-hydroxy-3-hydroxy methylbutyl)guanine] is a nucleoside analog, and in spite of its competent action, there are problems with acyclovir-resistant strains of herpesvirus. Even with the 
regular dose recommended for parenteral or topical uses, collateral effects are mentioned, such as neurotoxicity and renal dysfunction. Drugs with activity against DNA viruses, present a mechanism of action dependent on viral thymidine kinase, which requires phosphorylation, cellular metabolism of the drug, and a certain grade of sensitivity to viral polymerase (Cotarelo et al., 1999; Mibu et al., 2007). Macrophages from mice infected with herpesvirus simplex type 2 (HSV-2) demonstrated extrinsic antiviral resistence. This was observed only with the adherent peritoneal macrophage population. Such antiviral effects required viable macrophages, as the cell lysates did not inhibit virus growth (Morahan, Morse, Mc George, 1980).

Therefore, studies have been performed in order to investigate antiviral properties from natural sources, visualizing not only their use alone, but as a complement to synthetic antivirals, through the synergistic action between both. Extracts from plants, algae and essential oils from seeds or fruits presenting compounds with antiviral effects have been the most studied items within this category. Flavonoid compounds such as quercetin revealed decrease or inhibition of the yield of Herpes simplex virus (HSV 1), and also of type 2 virus, thanks to a probable virucidal action, as the result was an inhibition of viral DNA replication (Nolkemper et al., 2006).

Polysaccharides are reported as a complex group of macromolecules possessing a wide range of therapeutically important biological properties, and they are known to affect the growth of animal viruses. These compounds have been extracted from different algae species. Prunella vulgaris (L), a perennial plant commonly found in China and Europe, and two others such as brown algae Sargassum patens and Spirulina maxima present the active principle sulphated polysaccharide, with virucidal capacity in herpesvirus replication in vitro. Beside these, saponins are other example of compounds extracted from both Anagallis arvensi Primulaceae and a planktonic blue-green alga, Spirulina maxima, which among their several uses, present antiviral action (Amoros, Fauconnier, Gierre, 1987; Corona et al., 2002; Chiu et al., 2004; Zhu et al., 2004).

The phenolic compounds extracted from aromatic plants, seeds, stem bark, roots and spices that have been used as natural antiviral agents, are mentioned also in the literature. Eugenol (4-allyl-1-hydroxy-2-methoxybenzene), the most studied, is mainly found in oil of cloves and in essencial oils of cinnamon, and basil. This compound presents inhibitory effects on lipid peroxidation and an effective antivirus replication of either RNA or DNA virus. This antiviral has a mechanism of action that disables the viral lipidic envelope (Benencia, Courreges, 1999; Cota- relo et al., 1999; De Logu et al., 2000; Garcia et al., 2003; Minami et al., 2003).

More scientific investigations on this matter revealed that the essential oil from peppermint is able to exert a direct virucidal effect on herpesvirus (HSV), including an acyclovir resistant strain of HSV. It affected the virus before adsorption, but not after penetration into host cells. Considering the lipophilic nature of the oil, which enables it to penetrate the skin, it could be suitable for topical therapeutic use in herpes infection, mainly as adjuvant for synthetic drugs (Schumaker et al., 2003; Saddi et al., 2007).

The antiviral effects of mangiferin and isomangiferin were also evaluated through comparison with antiviral control drugs as acyclovir, idoxuridine, and cyclocytidine. The action mode of these natural antiviral agents is presumably due their capability of inhibiting virus replication within cells (Thompson, Dragar, 2004; Zheng, Lu, 1990).

Many of these antiviral agents can be used internally, as these plants and herb extracts were evaluated as nontoxic by appropriate tests, or they are flagrantly eatable, as confirmed by their prolonged use, as for instance, in the case of spices.

There are recent attempts to obtain a synergistic action between both, natural and synthetic antiviral agents. The advantages of such combinations are: a) dose decreasing of potentially toxic compounds, b) improvement of drug resistant viruses, and c) potentialization of the antiviral action (Hayashi et al., 1997).

In our previous work with phenolic compounds from spices, active effects were verified on the inhibition of the RNA viruses, like Parainfluenza (PI3) isolated from natural hosts, such as humans (Mancini-Filho et al., 2005). In this present study, the phenolic compounds fraction was evaluated from the spice rosemary (Rosmarinus officinalis, L), alone and in combination with synthetic antioxidants, aiming to verify their antiviral effects on DNA viruses, such as Herpes - type 1 .

\section{MATERIAL AND METHODS}

\section{Spice extraction}

The rosemary spice (Rosmarinus officinalis, L.) was acquired at a local market, in the city of São Paulo, Brazil. The aqueous extract was obtained from a $4 \mathrm{~g}$ sample of the spice, which was incubated in $40 \mathrm{~mL}$ of hot water $\left(80^{\circ} \mathrm{C}\right)$ while shaking for $10 \mathrm{~min}$, followed by centrifugation at $3,000 \mathrm{~g}$ for $20 \mathrm{~min}$. After residue removal, water was added to the supernatant to complete $40 \mathrm{~mL}$. The amount of dry material in the extract was determined gravimetrically. The 
determination of the total phenolic compounds was accomplished by spectrophotometry, using Folin - Denis' reagent and catechins as standard. The antioxidant activity was measured in the $\beta$-carotene and linoleic acid model system, as previously described by Mancini-Filho et al. (2005).

\section{Cells and virus}

African Green Monkey Kidney cells (VERO), provided by the Instituto Adolfo Lutz, São Paulo, Brazil, were cultured in Leibovitz-15 $\left(\mathrm{L}_{15}\right)$ medium and supplemented with 5\% fetal calf serum (FCS) from CUTILAB ${ }^{\circledR}$, Brazil, with the addition of antibiotics.

Herpes Virus type I (HSV-1) was obtained from Instituto de Medicina Tropical, São Paulo, Brazil; its titer (expressed by TCID $_{50}$ ) was determined by cytopathic effect in cells culture.

\section{$50 \%$ tissue culture infectious doses $\left(\operatorname{TCID}_{50 \%}\right)$}

VERO cells were used to prepare the viral microtitration in 96-wells culture plates (Nunc Multidish ${ }^{\circledR}$ USA). HSV-1 virus was ten-fold diluted $\left(10^{-1}\right.$ to $\left.10^{-10}\right)$ in $\mathrm{L}_{15}$ medium and was inoculated in each plate well, with $25 \mu \mathrm{L}$ of each dilution in 5 wells, and incubated for $2 \mathrm{~h}$ at $4^{\circ} \mathrm{C}$, after which a further $25 \mu \mathrm{L}$ of $\mathrm{L}_{15}$ medium was added. The micro plate was incubated for seven days at $37^{\circ} \mathrm{C}$ in $\mathrm{CO}_{2}(5 \%)$, and examined daily for evidence of CPE. Titers of all cases were determined by Reed Muench's method.

\section{Antiviral assays}

The antiviral activity of rosemary (Rosmarinus officinalis, L.) extract was assayed using VERO cells grown in 96-wells culture microplates (Nunc Multidish-USA). Cells were infected with 10,000 TCID $_{50 \% \mathrm{~mL}}$ of HSV-1 (titer TCID $\left._{50} 10^{9,5}\right)$, previously treated with $300 \mathrm{ppm}$ from rosemary extract $(\mathrm{v} / \mathrm{v})$ for $3 \mathrm{~h}$ at $4{ }^{\circ} \mathrm{C}$. The cells inoculated were incubated for seven days at $37^{\circ} \mathrm{C}$ in $\mathrm{CO}_{2}(5 \%)$. The virus inhibition was measured by the decrease in percentage of the CPE levels (formula IP) (Benencia, Courreges, 1999).

\section{Attachment assay}

This test described by De Logu et al. (2000) was performed as follows: VERO cells monolayer grown in 24 wells culture plate, were pre-chilled at $4{ }^{\circ} \mathrm{C}$ for $2 \mathrm{~h}$. The medium was aspirate and the cell monolayer was infected with 1,000 $\mathrm{TCID}_{50 / \mathrm{mL}}$ of HSV-1, in absence or presence of $300 \mathrm{ppm}$ from rosemary extract. After incubation of infected cells at $4{ }^{\circ} \mathrm{C}$ for $3 \mathrm{~h}$, the medium was drawn to remove the non-adsorbed viruses. Then the monolayer was washed with PBS three times and overlaid with maintenance medium. The culture was maintained for seven days at $37^{\circ} \mathrm{C}$ in $\mathrm{CO}_{2}(5 \%)$. The percent of inhibitory effect of rosemary for HSV-1 attachment to the cells was calculated using the formula for calculation of virus inhibition percentage (Benencia, Courreges, 1999).

\section{Synergistic effect}

With both, 300 ppm from natural (rosemary extract) and $100 \mathrm{ppm}$ from synthetic antioxidant (butyl hydroxyl toluene - BHT), the synergistic effect was assayed by the mentioned antiviral assay using rosemary alone and in combination with synthetic antioxidant, at the same time of contact with HSV-1 diluted at $10^{-2}$ TCID $_{50 \%-m l}(\mathrm{~V} / \mathrm{V})$. Beyond this, the synergistic effect between natural and synthetic antioxidants was assayed by lipidic oxidation inhibition.

Formula for virus inhibition percentage calculation (Benencia, Courreges, 1999):

$\mathrm{IP}=\frac{1-\left[\left(\mathrm{TCID}_{50 \% / \mathrm{mL}} \text { of HSV-1 treated with Rosemary }\right)\right] \mathrm{X} 100 \%}{\text { TCID }_{50 \% \mathrm{~mL}} \text { titer of Control HSV-1 }}$

\section{RESULTS AND DISCUSSION}

In the present work, the results were obtained by means of antiviral evaluations of either natural antioxidant agents from rosemary (Rosmarinus officinalis, L) alone or in combination with a synthetic antioxidant (butyl hydroxy toluene - BHT). These data, concerning HSV-1 replication in cells, revealed similar levels of inhibition percentage (IP) of the viral replication $(82.0 \%$ and $82.5 \%$ ). These antiviral action is attributed to rosemary and rosemary combined with BHT, respectively (Tables I and II).

TABLE I - Viral inhibition action of natural antioxidant from rosemary (Rosmarinus officinalis, L.) $300 \mathrm{ppm}$ on HSV-1 replication in vero cells

\begin{tabular}{ccc}
\hline $\begin{array}{c}\text { Contact } \\
\text { Virus X Antioxidants } \\
\text { (hours) }\end{array}$ & $\begin{array}{c}\text { HSV-1 } \\
\text { TCID }_{50 \% / m L}\end{array}$ & $\begin{array}{c}\text { Percent of Virus } \\
\text { Inhibition }\end{array}$ \\
\hline 0 & 10,000 & NONE \\
3 & 1,800 & 82.0 \\
\hline
\end{tabular}

Formula to determine the virus inhibition percentage: 
$\mathrm{IP}=\frac{1-\left[\left(\mathrm{TCID}_{50 \% \mathrm{~mL}} \text { of HSV-1 treated with Rosemary }\right)\right] \mathrm{X} 100 \%}{\mathrm{TCID}_{50 \% / \mathrm{mL}} \text { titer of Control HSV-1 }}$

TABLE II -Viral inhibition of the natural antioxidant from rosemary (Rosmarinus officinalis, L.) $300 \mathrm{ppm}$ and synthetic antioxidant butyl hydroxyl toluene (BHT) 100 ppm on HSV-1 replication in VERO cells

\begin{tabular}{ccc}
\hline $\begin{array}{c}\text { Contact } \\
\text { Virus X Antioxidants } \\
\text { (hours) }\end{array}$ & $\begin{array}{c}\text { HSV-1 } \\
\text { TCID }_{50 \% / m L}\end{array}$ & $\begin{array}{c}\text { Percent of Virus } \\
\text { Inhibition }\end{array}$ \\
\hline 0 & 10,000 & NONE \\
3 & 1,750 & 82.5 \\
\hline
\end{tabular}

Formula to determine the virus inhibition percentage:

$\mathrm{IP}=\frac{1-\left[\left(\mathrm{TCID}_{50 \% / \mathrm{mL}} \text { of HSV-1 treated with Rosemary }+ \text { BHT }\right)\right] \mathrm{X} 100 \%}{\mathrm{TCID}_{50 \% \text { mL }} \text { titer of Control HSV-1 }}$

Regarding to the attachment assay, the observed results were of a percent inhibition (PI) of the $85.0 \%$ and $86.3 \%$ on HSV-1 replication in VERO cells obtained from both antioxidants: rosemary and rosemary plus BHT, respectively (Tables III and IV).

TABLE III - Inhibitory action of natural antioxidant from rosemary (Rosmarinus officinalis, L.) $300 \mathrm{ppm}$ on attachment cells for HSV-1

\begin{tabular}{ccc}
\hline $\begin{array}{c}\text { Contact } \\
\text { Virus X Antioxidants } \\
\text { (hours) }\end{array}$ & $\begin{array}{c}\text { HSV-1 } \\
\text { TCID }_{50 \% / m L}\end{array}$ & $\begin{array}{c}\text { Percent of Virus } \\
\text { Inhibition }\end{array}$ \\
\hline 0 & 1,000 & NONE \\
3 & 150 & 85.0 \\
\hline
\end{tabular}

Formula to determine the virus inhibition percentage:

$\mathrm{IP}=\frac{1-\left[\left(\mathrm{TCID}_{50 \% \mathrm{~mL}} \text { of HSV-1 in presence of Rosemary }\right)\right] \mathrm{X} 100 \%}{\mathrm{TCID}_{50 \% \mathrm{~mL}}}$

TABLE IV - Inhibitory action of natural antioxidant from rosemary (Rosmarinus officinalis, L.) $300 \mathrm{ppm}$ and synthetic antioxidant of butyl hydroxyl toluene (BHT) $100 \mathrm{ppm}$ on attachment cells for HSV-1

\begin{tabular}{ccc}
\hline $\begin{array}{c}\text { Contact } \\
\text { Virus X Antioxidants } \\
\text { (hours) }\end{array}$ & $\begin{array}{c}\text { HSV-1 } \\
\text { TCID }_{50 \% / m L}\end{array}$ & $\begin{array}{c}\text { Percent of Virus } \\
\text { Inhibition }\end{array}$ \\
\hline 0 & 10,000 & NONE \\
3 & 137 & 86.3 \\
\hline
\end{tabular}

Formula to determine the virus inhibition percentage:

$\mathrm{IP}=\frac{1-\left[\left(\mathrm{TCID}_{50 \% \mathrm{~mL}} \text { of HSV-1 in presence of Rosemary }+\mathrm{BHT}\right)\right] \mathrm{X} 100 \%}{\mathrm{TCID}_{50 \% \mathrm{~mL}} \text { titer of Control HSV-1 }}$

Nolkemper et al. (2006) also reported the antiviral action on both types of HSV, HSV-1 and HSV-2, in experiments using spices that presented significant reduction of these virus replications in $\mathrm{RC}-37$ cells.

Respecting to the evaluation of the lipidic oxidation inhibition regarding both, the natural and the synthetic antioxidants, a synergistic effect was observed between them (Figure 1).

No cytotoxic effect was observed in VERO cells in contact with $300-100 \mathrm{ppm}$ of both, the natural and synthetic antioxidants. The normal cells with antioxidants (used as control) and the cytopathic effects from HSV-1 in VERO cells previously in contact with antioxidant, or

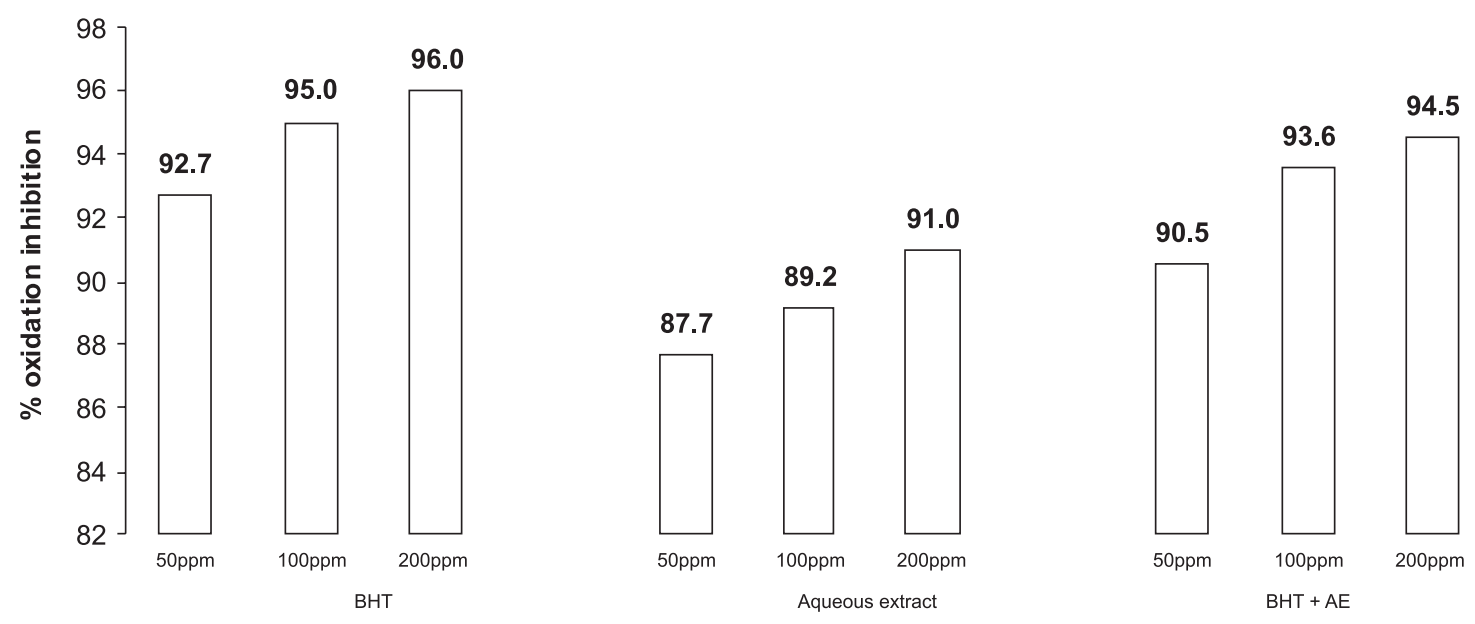

FIGURE 1 - Percents of the oxidation inhibition from BHD and aqueous extracts (AE) of rosemary (Rosmarinus officinalis L.) and its synergic activity. 


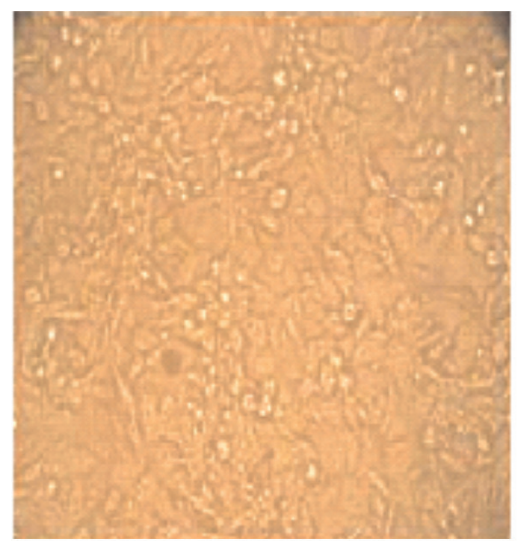

a) VERO cells control

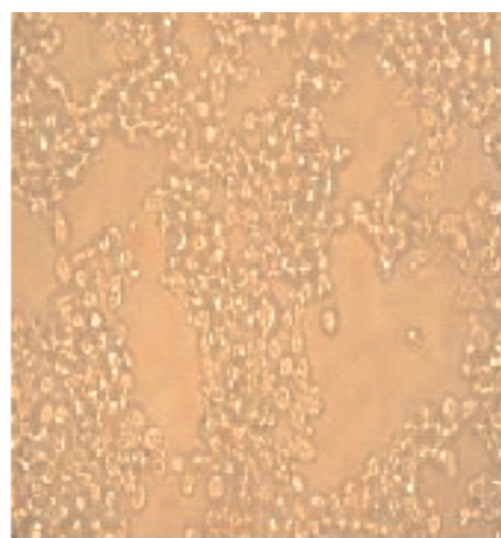

b) Total cytopathic effect (CPE)

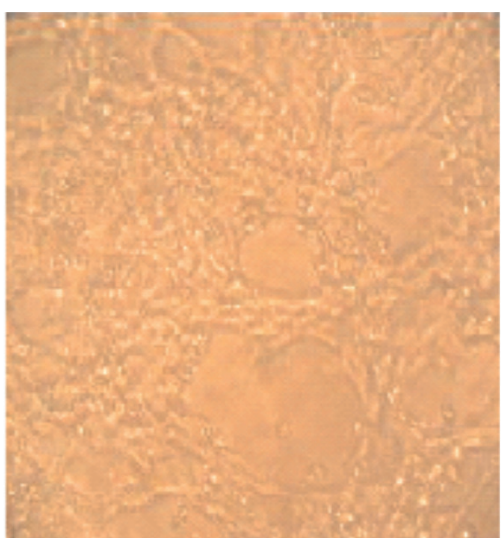

c) Cells infected with HSV-1 in presence of Rosemary, cytopathic effect $(\mathrm{CPE})$ reduction

FIGURE 2 - The HSV-1 cytopathic effect and its inhibition by the antioxidant rosemary.

not, are shown in Figure 2 (a, b, c). Garcia et al. (2003) reported that a range of $100-150 \mathrm{ppm}$ of essential oils from aromatic plant extracts (San Luis - Argentina) demonstrated virucidal activity against HSV-1. This activity was obtained by direct contact between the virus and the extract, for $3 \mathrm{~h}$ before its inoculation in cell culture.

An inhibition level of $99.9 \%$ on the HSV-1 yield was observed, when the extract from Cordia salicifolian was added in Hela cell monolayers before the virus inoculation, during experiments performed by Palamara et al. (1995).

In both of these situations, the HSV-1 was inhibited either by viral inactivation obtained through direct contact between virus and the extract, or by the virus inhibition of the cell receptor contact.

An antiviral without interference on cellular metabolism, the glutathione (GSH), was reported by Palamara et al. (1995). This is because an antiviral, such as the DLGalactan, extracted from the red seaweed Gymnogongrus torulosus, possesses an action mode of interference on the binding of the surface glycoprotein of the viral envelope to the cell receptor (Pujol et al., 2002).

These glycoprotein potencies for antiviral activity are suggested to depend on the molecules' binding affinity for fetuin (Ooi et al., 2008).

By afore mentioned test, all viral titrations of the HSV-1 were performed in VERO cells, observing their cytopathic effect (CPE) for seven days. The results of these experiments showed a range of $72-96 \mathrm{~h}$ for total CPE of virus controls. Mean titers of HSV-1 were $10^{9.5} \mathrm{TCID}_{50 / \mu \mathrm{L}}$. In order to evaluate antiviral activity from both, natural and synthetic antioxidants, antiviral tests with HSV-1 virus diluted at $10^{-3}-10^{-4}$ were employed.

\section{CONCLUSIONS}

Based on these data demonstrated in the results of this study, it is possible to argue that aqueous extract from rosemary spice (Rosmarinus officinalis, L) possesses antioxidant activity with antiviral action. This finding was confirmed by the inhibitor of lipidic oxidation test, as well as by the HSV-1 replication in VERO cell inhibition assays. Concentrations of $100 \mathrm{ppm}$ and $300 \mathrm{ppm}$ for rosemary and butyl hydroxy toluene (BHT), respectively, were considered appropriate for these tests, taking in account the lack of toxicity in this condition.

These experiments with HSV-1 replication in VERO cells, in the presence or absence of both, natural and synthetic antioxidants, have verified the virus inactivation and virus replication inhibition, in the range of 85 to 86 percent.

Therefore, considering the kind of antiviral actions of either natural extract or synthetic antioxidants, they could be suggested as virucidal agents, and also inhibitors of the viruses replication.

Although a synergistic effect has been verified by lipidic inhibition between these natural and synthetic antioxidants, it was not verified respecting the reinforcement of antiviral action from rosemary spice against the HSV-1, in this study.

The authors of this present investigation intend to reinforce and collaborate with experiments on herpesvirus therapy using extract from natural sources as adjuvants for synthetic antiviral agents.

\section{ACKNOWLEDGMENTS}

The authors are grateful to CNPq for the financial 
support from Process number 470937-03, and extend their thanks to Mrs Luzia da Purificação, for her services in the Laboratory of Virology, and to the Tropical Medicine Institute, for donation of the HSV-1 Sample.

\section{REFERENCES}

AMOROS, M.; FAUCONNIER B.; GIERRE, R.L. In vitro antiviral activity of a saponin from Anganallis arvensis, Primulaceae, against herpes simplex virus and poliovirus. Antiviral Res., v.8, n.1, p.13-25, 1987.

BENENCIA, F.; COURREGES, M.C. Antiviral activity of sandalwood oil against herpes simplex -1 and -2 . Phytomedicine, v.6, n.2, p.119-123, 1999.

CORONA, A.H.; NIEVES, I.; MECKES, M.; CHAMORRO, G.; BARRON, B.L. Antiviral Activity of Spirulina maxima against simplex vírus type 2. Antiviral res., v.56, n.3, p.279285, 2002.

COTARELO, M.; CATALAN, P.; SANCHEZ-CARRILLO, C.; MENASALVAS, A.; CERCENADO, E.; TENORIO, A.; BOUZA. E. Cytopathic effects inhibition assay for determining the in-vitro susceptibility of herpes virus to antiviral agents. J. Antimicrob. Chemotherapy., v.44, n.5, p.705-708, 1999.

CHIU, L.; ZHU, W.; OOI, V.E. A polysaccharide fraction from medicinal herb Prunella vulgaris downregulates the expression of herpes simplex virus antigen in Vero cells. $J$. Ethnopharmacol., v.93, n.1, p.63-69, 2004.

DE LOGU, A.; LOY, G.; PELLERANO, M.L.; BONSIGNORE, L.; SCHIVO, M.L. Inactivation of HSV-1 and HSV-2 and prevention of cell-to-cell virus spread by Santolina insularis essencial oil. Antiviral Res., v.48, n.3,p.177-185, 2000.

GARCIA, C.C.; TALARICO,L.;ALMEIDA, N.; COLOMBRES, S.; DUSCHATZKY, C.; DAMONTE, E.B. Virucidal activity of essential oils from aromatic plants of San Luis, Argentina. Phytother. Res., v.17, n.9., p.1073-1075, 2003.

HAYASHI, K.; HAYASHI, T.; OTSUKA, H.; TAKEDA, Y. Antiviral activity of 5, 6, 7,-Trimethoxyflavone and its potentiation of the antiherpes activity of acyclovir. $J$. Antimicrob. Chemother., v.39, n.6, p.821-824, 1997.
MANCINI FILHO, J.; TORRES, R.P.; PINTO, J.R.; MENDONÇA, R.M.Z.; MANCINI, D.A.P. Synergistic effects of synthetic and natural spice antioxidants on antiviral action against Parainfluenza virus. Boll. Chim. Farmaceutico, v.44, n.4, p.85, 2005.

MIBU, N., YOKOMIZO, K., MIYATA, T., SUMOTO, K. $\mathrm{N}$-monocarbamoyl derivates of symmetrical diamines with antiviral activity. Chem. Pharm. Bull., v.55, n.9, p.1406$141,2007$.

MINAMI, M.; KITA, M.; NAKAYA, T.; YAMAMOTO, T.; KURIYAMA, H.; IMANISHI, J. The inhibitory effect of essencial oils on herpes simplex virus type-1 replication in vitro. Microbiol. Immunol., v.47, n.9, p.681-684, 2003.

MORAHAN, P.S.; MORSE, S.S.; MCGEORGE, M.G. Macrophage extrinsic antiviral activity during herpes simplex virus infection. J. Gen. Virol., v.46, n.2, p.291300, 1980.

NOLKEMPER, S.; REICHLING, J.; STENTZING, F.C.; CARLE, R.; ACHNITZLER. P. Antiviral effect of aqueous extracts from species of the Lamiaceas family against Herpes simplex virus type 1 and type 2 in vitro. Planta Med., v.72, n.15, p.1378-1382, 2006.

OOI, L.S.; WONG, E.Y.; CHIN, L.C.; SUN, S.S.; OOI, V.E. Antiviral and Anti-proliferative Glycoproteins from the Rhizome of Smilax glabra Roxb (Liliaceae) Am. J. Chin. Med., v.36, n.1, p.185-195, 2008.

PALAMARA, A.T.; PERNO, C.F.; CIRIOLO, M.R.; DINI, L.; BALESTRA, E.; D'AGOSTINI, C.; DI FRANCESCO, P.; FAVALLI, C.; ROTILIO, G.; GARACI, E. Evidence for antiviral activity of glutathione: in vitro inhibition of Herpes simplex type 1 replication. Antiviral. Res., v.27, n.3, p.237-253, 1995.

PUJOL, C.A.; ESTEVEZ, J.M.; CARLUCCI, M.J.; CIANCIA, M.; CEREZO, A.S.; DAMONTE, E.B. Novel DL-galactan hybrids from the red seaweed Gymnogongrus torulosus are potent inhibitors of herpes simplex virus and dengue virus. Antimicrob. Agents Chemother., v.13, n.2, p.83-89, 2002.

SCHUMACHER, A.; REICHLING, J.; SCHNITZLER, P. Virucidal effect of peppermint oil on the enveloped viruses herpes simplex virus type 1 and type 2 in cell culture. Phytomedicine, v.10, n.6-7, p.504-510, 2003. 
SADDI, M.; SANNA, A.; COTTIGLIA, F.; CHISU, L.; CASU, L.; BONSIGNORE, L.; DE LOGU, A. Anti-herpesvirus activity of Artemisia arborescencens essential oil and inhibition of lateral difusion in Vero cells. Ann. Clin. Microbiol. Antimicrob., v.6, n.10, 2007.

THOMPSON, K.D.; DRAGAR, C. Antiviral activity of Undaria pinnatifida against herpes simplex virus. Phytother. Res., v.18, n.7, p.551-555,2004.
ZHENG, M.S. \& LU, Z.Y. Antiviral effect of mangiferin and isomangiferin on herpes simplex virus. Clin. Med. J., v.103, n.2, p.160-165,1990.

ZHU, W.; CHIU, L.C.M.; OOI, V.E.C.; ANG JR, P.O. Antiviral property and mode of action of a sulphated polysaccharide from Sargassum patens against herpes simplex virus type 2. Int. J. Antimicrob. Agents, v.24, n.3, p.279-283, 2004.

Recebido para publicação em 08 de abril de 2008. Aceito para publicação em 02 de outubro de 2008. 